\title{
Review \\ Insulin-like growth factors and insulin-like growth factor binding proteins in mammary gland function
}

\author{
Emma Marshman and Charles H Streuli
}

School of Biological Sciences, University of Manchester, UK

Correspondence: Emma Marshman, School of Biological Sciences, Stopford Building, University of Manchester, Oxford Road, Manchester M13 9PT, UK. Tel: +44 161275 5583; fax: +44 161275 5958; e-mail: emma.marshman@man.ac.uk

\begin{abstract}
Insulin-like growth factor (IGF)-mediated proliferation and survival are essential for normal development in the mammary gland during puberty and pregnancy. IGFs interact with IGF-binding proteins and regulate their function. The present review focuses on the role of IGFs and IGF-binding proteins in the mammary gland and describes how modulation of their actions occurs by association with hormones, other growth factors and the extracellular matrix. The review will also highlight the involvement of the IGF axis in breast cancer.
\end{abstract}

Keywords: breast cancer, insulin-like growth factor, insulin-like growth factor binding proteins, mammary gland

\section{Introduction}

The insulin-like growth factors (IGF)-I and -II are singlechain polypeptides that share $62 \%$ homology in their amino acid sequences. Although at least two receptors for IGFs exist, the primary signalling receptor through which both IGF-I and IGF-II exert their biological actions is the type I insulin-like growth factor receptor (IGF-IR). The IGFIR binds IGF-I and IGF-II with high affinity $\left(K_{d} \sim 1-2 \mathrm{nM}\right)$ and binds insulin with an affinity that is $500-1000$ times lower. IGFs can also bind and activate the insulin receptor [1]. IGFs are synthesized and secreted by many tissues, and they can act locally as autocrine or paracrine factors, or as endocrine factors that circulate in the plasma.

IGFs have both immediate and long-term effects on various cellular activities. For example, IGF-I exerts an acute anabolic action on protein and carbohydrate metabolism by increasing the cellular uptake of amino acids and glucose by stimulating glycogen and protein synthesis [2]. IGFs also have long-term impact on cell proliferation, differentiation, migration and survival (for general reviews on IGF function, see $[3,4]$ ).

The actions of IGFs can be modulated by interaction with a family of six insulin-like growth factor-binding proteins (IGFBPs), IGFBP-1 to IGFBP-6, which share 40-60\% amino acid identity. All six IGFBPs have 16-18 conserved cysteine residues in the amino and carboxy terminal regions. The majority of circulating IGFs (>97\%) are bound to IGFBPs, particularly to IGFBP-3, with an affinity equal to or greater than that of the IGF-IR [5]. By binding IGF-I and IGF-II, IGFBPs regulate the bioavailability of IGFs in the circulation; however, their functions at the cellular level are not fully understood. IGFBPs have been reported to both inhibit and enhance IGF-I action depending on the system under investigation and the IGFBP studied.

$\mathrm{ECM}=$ extracellular matrix; $\mathrm{EGF}=$ epidermal growth factor; $\mathrm{ER}=$ oestrogen receptor; $\mathrm{GH}=$ growth hormone; GHR = growth hormone receptor; IFN = interferon; IGF = insulin-like growth factor; IGFBP = insulin-like growth factor-binding protein; IGF-IR = type I insulin-like growth factor receptor; IRS-1 = insulin-receptor substrate-1; $K_{\mathrm{d}}=$ dissociation constant; MAPK = mitogen-activated protein kinase; PI3K = phosphatidylinositol 3-kinase; STAT-3 = signal transducer and activator of transcription-3; TEB = terminal end bud. 
In common with IGFs, IGFBPs have complex patterns of expression and physiological regulation both during embryogenesis and in the adult, and they play an important role in the development and function of a number of key systems. The present review will discuss the function of IGFs and their binding proteins in the normal mammary gland, and will consider their role in breast cancer.

\section{Regulation and expression of IGFs in the mammary gland}

The hormonal control of mammary gland development is complex and involves ovarian, adrenal and pituitary hormones. One such pituitary hormone, growth hormone $(\mathrm{GH})$, is essential for mammary gland development because mice lacking the growth hormone receptor (GHR) have a severely compromised ductal network [6]. IGF-I is the primary mediator of the actions of $\mathrm{GH}$, since mammary ductal development is considerably diminished in hypophysectomized rats and can be restored by mammary implants containing IGF-I [7,8].

Although GH regulates IGF-I production from the liver, which is the major circulating source of IGFs, it can also modulate locally produced IGFs. Indeed, treatment of mammary tissue with $\mathrm{GH}$ induces a dose-dependent increase in IGF-I mRNA in organ culture [8,9], consistent with a key role for locally produced IGFs, under the control of systemic hormones.

IGFs are synthesized by stromal cells of the mammary connective tissue (i.e. fibroblasts and adipocytes). This supports the well-known concept that stromal-epithelial interactions are vital for full mammary gland development. IGF-I and IGF-II mRNA are thus expressed in stromal cells, while the IGF-IR is present within the epithelium [10]. The GHR is also present in stroma, and tissue recombination experiments indicate that GHR expression by stromal cells, rather than the epithelium, is essential for mammary development [6]. Moreover, GH induces IGF-I mRNA in isolated epithelium-free mammary stroma [8]. It thus appears that GH activates the GHR within stromal fibroblasts and/or adipocytes, thereby inducing expression of IGF-I, which then acts on the IGF-IR in the epithelium (Fig. 1). Interestingly, a comparison of IGF-I mRNA expression in mammary fat pads with and without glandular epithelium revealed higher stromal expression when the epithelium is present [11]. This suggests the involvement of reciprocal interactions whereby the epithelial cells feedback on the stromal cells to modulate production. One further issue of note is the lack of studies on the effect of IGFs on mammary stromal cells. Since IGF-I is important in regulating adipocyte differentiation in cultured cells [12], this is an area that may deserve future attention.

In addition to the expression of IGFs in stroma, mRNA has the mammary gland, particularly during ductal development [13]. IGFs are strongly expressed in terminal end buds (TEBs), which are the main proliferative units of the pubertal developing gland [9]. Interestingly, IGF-II mRNA appears in sporadic epithelial cells within the ducts and alveoli of the pregnant gland [13]. The mechanism responsible for initiation of expression of IGFs in the epithelium has not been identified, but it may be through oestrogen, which causes a twofold to threefold increase in the expression of IGF-I mRNA in human breast tissue implanted as xenografts in nu/nu mice [14]. Given that the oestrogen receptor (ER) is mainly expressed within the mammary epithelium but not in the cells that undergo DNA synthesis [15], it is possible that oestrogen induces the epithelial expression of IGFs, which then mediates a paracrine growth signal for neighbouring epithelial cells (Fig. 1). Whether these paracrine mechanisms involving IGF-I produced within the stroma and the epithelium are the major driving force for proliferation in the mammary gland has not yet been fully explored. However, other locally produced growth factors (e.g. RANK ligand) are also essential at specific times of development such as during alveolargenesis [16].

\section{The actions of IGFs within the mammary gland}

Activation of the IGF-IR occurs following IGF-I binding to the $\alpha$-subunit of the IGF-IR on epithelial cells, leading to autophosphorylation of the $\beta$-subunit by an intrinsic tyrosine kinase. These events can lead to the activation of a number of downstream pathways including the insulinreceptor substrate/phosphatidylinositol 3-kinase (PI3K)/ protein kinase B pathway and the Ras/Raf/mitogenactivated protein kinase (MAPK) pathway (for a review on mechanisms of IGF signalling, see [17]). IGFs play a key role in proliferation and survival in the mammary gland, particularly during puberty and pregnancy. It has been suggested that the MAPK pathway drives the cell proliferative response whereas the PI3K pathway is required for survival effects [18], but it is probable that the cellular response depends on the concentration and the time course. Additionally, crosstalk between these pathways has been demonstrated in the human breast cancer cell line MCF-7 [19].

\section{IGF-mediated proliferation}

Proliferation occurs during the two major stages of mammary gland development. During puberty, there is extensive ductal lengthening through proliferation of cells in the TEBs located at the tips of the epithelial ducts accompanied by side branching of mature ducts. During pregnancy, the gland continues to proliferate and differentiate, with the formation of secretory alveoli in preparation for lactation. Evidence for an essential role of IGFs in mammary epithelial cell proliferation is provided by both culture and animal models. 


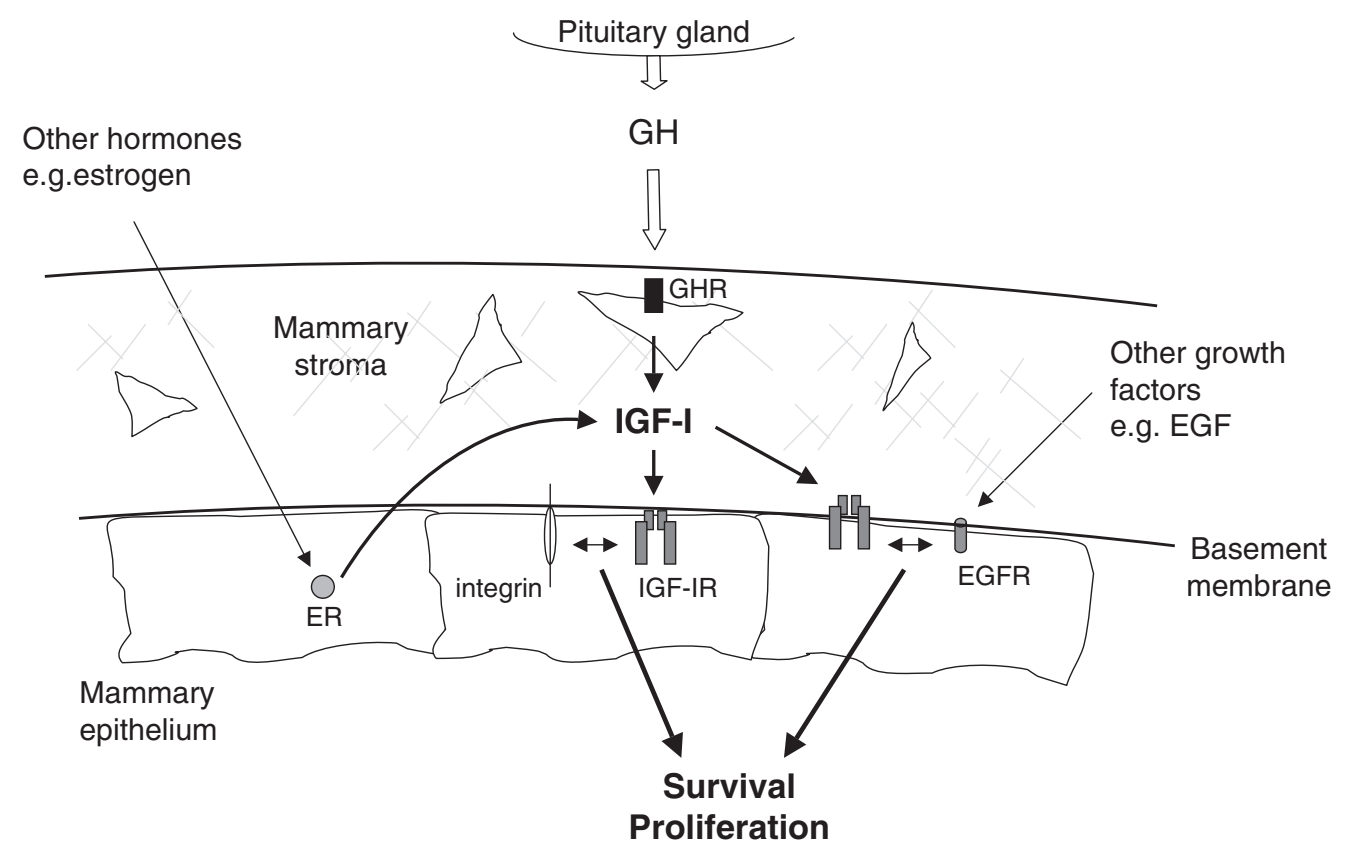

Insulin-like growth factor-I (IGF-I) signalling networks in the mammary gland. Growth hormone (GH) acting on the growth hormone receptor (GHR) on stromal cells induces IGF-I release, which subsequently acts at the type I insulin-like growth factor receptor (IGF-IR) on epithelial cells to mediate survival and proliferation. Oestrogen can also induce IGF-I expression, which may then act on adjacent mammary epithelial cells. The basement membrane provides an interface between stroma and epithelial cells, and it can contribute to the signals required for mammary development via integrin receptors. Epidermal growth factor (EGF) can synergize with IGF-I, and IGF-I can transactivate the EGF receptor (EGFR). ER, oestrogen receptor.

IGF-I maintains the growth of normal mammary epithelial cells in culture $[20,21]$. It is a potent mitogen for mammary epithelial cells and, in combination with mammogenic hormones, IGF-I induces ductal growth in mammary gland explant cultures [13]. IGF-I null mice have deficient mammary development with reductions in the number of TEBs, ducts and the per cent of the fat pad occupied by glandular elements [9]. This phenotype is partially restored by administration of des(1-3)IGF-I [9]. Results gained from transplantation studies indicate there is also a significant reduction of cell proliferation within the TEBs of the IGF-IR null pubertal mammary gland, accompanied by a decrease in the size and number of the TEBs, and by considerably diminished ductal network and associated branching [22]. Interestingly, the loss of ductal development in the IGF-IR null mammary gland is largely reversed during pregnancy, suggesting the activation of compensatory pathways for proliferation.

\section{IGF-mediated survival}

IGFs now appear to be one of the essential survival factors for the mammary epithelium, although other factors such as epidermal growth factor (EGF) and its homologues also deliver intracellular signals that suppress apoptosis [23]. Direct evidence for IGFs as survival factors comes from culture studies. IGF-I or IGF-II can suppress the apoptosis of mammary epithelial cells induced by serum withdrawal [24]. It has recently been established that this is achieved through PI3K and MAPK signals that ultimately inhibit the activity of the proapoptotic protein BAD [23].

During pregnancy, there is inhibition of epithelial apoptosis by survival factors. Following lactation and weaning, however, involution occurs in which survival signals are removed/neutralized and the alveolar epithelial cells die by apoptosis [25-27]. Evidence for the role of IGFs in this process has been gained from transgenic mouse models. Involution is delayed in mice overexpressing human IGF-I or des(1-3)IGF-I due to reduced alveolar apoptosis $[28,29]$. Similarly, apoptosis is reduced, functionally intact lobuloalveolar alveoli persist and involution is delayed in IGF-II-overexpressing mice [30]. The mechanism for IGFmediated mammary cell survival in vivo has not been established, but it may involve components of the PI3K signalling pathway, as mice expressing an activated form of protein kinase $B$, which acts downstream of PI3K, show extensively delayed involution [31,32]. Since protein kinase $B$ can integrate a variety of survival signals, however, it is now important to determine whether genetically altered mice with absent or mutated proximal components within the IGF signalling axis have defective 
mammary apoptosis in vivo, but such studies have not yet been performed.

\section{Crosstalk between IGFs and other factors}

Although IGFs drive specific intracellular signalling pathways that are involved with epithelial cell proliferation and survival, their ability to regulate the cell phenotype is dependent on crosstalk with other molecules within the mammary gland.

IGF-I synergizes with oestrogen in TEB formation [33], and the combination can stimulate ductal morphogenesis in IGF-I null mice [9]. One possibility is that oestrogen activates the IGF-IR, as occurs in the uterus [34,35]. However, most of the work to elucidate the mechanism of crosstalk has been gained using breast cancer cell lines. The interaction between IGFs and oestrogens will therefore be explored further in the context of mammary gland malignancy (see "IGF axis and oestrogen in breast cancer" section below).

IGFs also cooperate with EGF to increase mammary epithelial cell proliferation. Whereas IGF-I and EGF can induce expression of early G1-type cyclins in cultured mammary cells, IGF-I is specifically required to traverse the G1-S checkpoint [36]. The EGF receptor can act as a nodal point for interception of several classes of signal, including G-protein-coupled receptors and integrins $[37,38]$, and can also be activated indirectly by IGF-I [23]. Indeed, IGF-I partially mediates its survival effect on mammary epithelial cells through transactivation of the EGF receptor and the consequent stimulation of MAPK [23] (Fig. 1).

The extracellular matrix (ECM), particularly the specialized matrix known as the basement membrane, plays a key and direct role in mammary epithelial physiology $[39,40]$. The basement membrane surrounds the mammary ducts and alveoli, and it contains laminin, nidogen, heparan sulphate proteoglycan and collagen IV [27]. Not only does the basement membrane provide a structural interface between the mammary stroma and the epithelium (Fig. 1), it also contributes to proliferation, survival and differentiation of mammary epithelial cells by signalling through integrin receptors [41]. For example, activation of insulin-receptor substrate-1 (IRS-1) and PI3K by insulin, at supraphysiological concentrations that bind the IGF-IR, occurs to a greater extent when mammary epithelial cells are cultured on basement membrane compared with collagen I [24].

The mechanism for ECM-dependent control of IGF signalling has not been elucidated, but it may involve direct interactions between integrins and components of the IGF signalling pathways as occurs in other cell systems [42] signalling through protein tyrosine phosphatases [43]. Interestingly, IGF-IR binding is significantly increased when primary cultures of mammary epithelial cells are plated on laminin compared with other substrata such as collagen type I, collagen type IV and fibronectin [44]. The synergistic proliferative response between IGF-I and EGF is also more marked when cells are grown on laminin, in comparison with the nonspecific attachment factor poly-Llysine. In addition to the involvement of ECM adhesion in regulating IGF signalling, integrins directly activate IRS-I in breast cancer cells, further substantiating the idea that adhesion and IGF signalling networks cooperate with each other [45].

Together, these observations indicate that a more complex model for IGF signalling exists, rather than the conventional model involving linear pathways through MAPK and PI3K. Indeed, IGF signalling should now be thought of as just one component in a complex network of signals where a variety of extracellular inputs become integrated within the cell to produce multiple, yet carefully orchestrated, signalling outputs for controlling the balance between proliferation and survival.

\section{IGFBP expression in the mammary gland}

In addition to crosstalk with other hormones, growth factors and the ECM, IGFs are also regulated by association with IGFBPs. In comparison with IGFs, less is known about the function of IGFBPs in the normal mammary gland. The expression pattern of IGFBP mRNA in mice has been determined during ductal and alveolar development [46]. All six mRNAs are present in the TEBs of the pubertal virgin gland, with IGFBP-3 and IGFBP-5 appearing most prominently. IGFBP- 5 mRNA is present throughout the TEB, but IGFBP-3 mRNA is expressed in cells along the outer edge of the TEB in a pattern corresponding to cap cells, the putative stem cells of the mammary gland. IGFBP-3 mRNA and IGFBP-5 mRNA are also highly expressed in the stroma, in addition to the ductal and alveolar epithelium in the pregnant gland. In the pregnant gland, IGFBP-2 mRNA, IGFBP-4 mRNA and IGFBP6 mRNA can be detected but this is restricted to the stroma [46].

\section{IGFBPs as regulators of IGF-mediated effects}

Since IGFBPs have an equal or greater affinity for IGFs compared with the affinity of the IGF-IR, the presence of IGFBPs could inhibit IGF activity by decreasing levels of free IGFs available to activate the receptor (Fig. 2). Such a mechanism has been proposed based on a study examining the expression of IGFBPs in rat milk during involution. A dramatic increase in the concentration of IGFBP-5 is observed in rat milk 48 hours after the removal of the suckling young [47]. A similar change in the mRNA level occurs at this time, indicating that the IGFBP- 5 present in rat milk is derived from the gland and does not enter by 


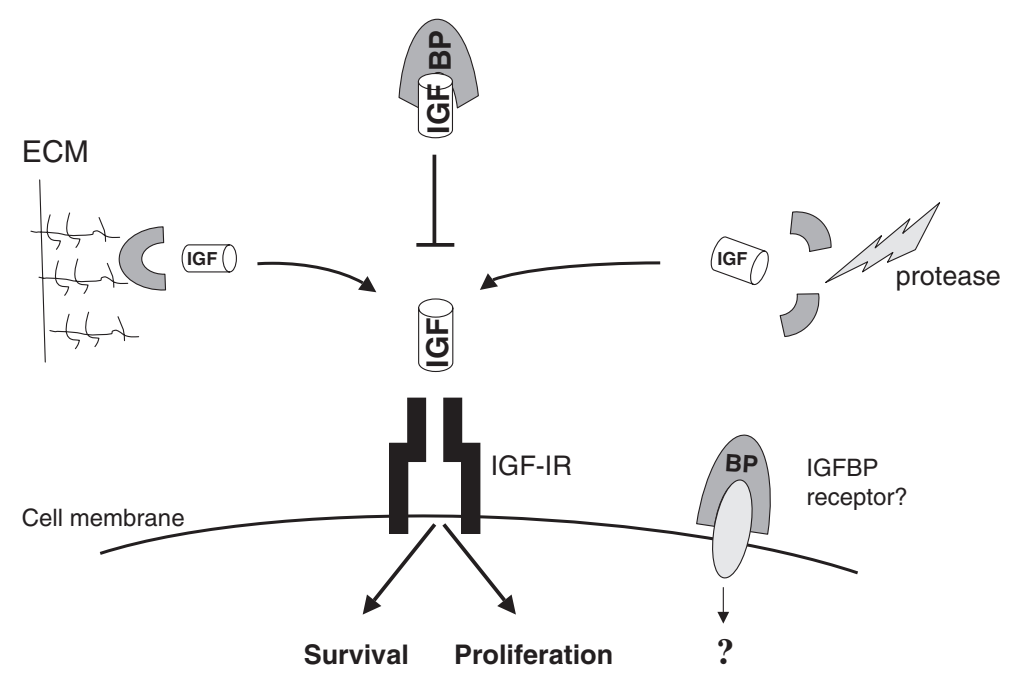

The interplay between insulin-like growth factor (IGF) and insulin-like growth factor binding proteins (IGFBPs). Interactions between IGF and IGFBPs can reduce free IGF levels, decreasing insulin-like growth factor receptor (IGF-IR) activation and inhibiting cellular response. Associations of IGFBPs with extracellular matrix (ECM) components can reduce the affinity of IGFBP for IGFs, thereby releasing bioactive IGF. The actions of proteases can also increase free IGF levels, since IGFBP fragments have reduced affinity for IGFs. IGFBPs may have direct effects mediated by as yet uncharacterized IGFBP receptors.

translocation from the circulation. Consistent with this, the most abundant IGFBP in the mouse mammary gland is IGFBP-5, expression of which is low during pregnancy and lactation but dramatically increases at involution (unpublished observations). This suggests that IGFBPs act locally within the mammary gland in close proximity to the cells involved in IGFBP production. It has thus been proposed that the presence of IGFBP-5 at involution inhibits the survival function of IGFs, leading to apoptosis.

One possible mechanism to explain the increased levels of IGFBP-5 after weaning is that prolactin withdrawal results in IGFBP-5 synthesis. Evidence for this is provided by treating rats with prolactin at the same time as pup removal, resulting in a 90\% inhibition of IGFBP-5 appearance in milk [47]. Prolactin may regulate IGFBP-5 expression indirectly through interferon regulatory factor-1 (IRF-1), since mice lacking IRF-1 in the mammary gland have increased IGFBP-5 expression and accelerated involution [48]. An alternative possibility is that IGFBP-5 expression is induced by a cytokine that activates the signal transducer and activator of transcription-3 (STAT3). Pup removal in wild-type mice dramatically activates STAT-3, an event that is functionally linked to mammary apoptosis since mice lacking STAT-3 in their mammary glands have both delayed involution and a reduced upregulation of IGFBP-5 [49].

A model thus emerges where, during pregnancy and lactation, $\mathrm{GH}$ increases IGF-I synthesis and prolactin represses
IGFBP-5 synthesis to maximize the survival and proliferative effects of IGF-I. Following weaning, however, the loss of prolactin and concomitant downregulation of IRF-1, together with the upregulation of a cytokine that activates STAT-3, leads to IGFBP-5 expression, thereby inhibiting IGF survival signalling and inducing mammary epithelial apoptosis. Although important, the IGF axis does not act alone in regulating mammary involution, as studies with genetically altered mice indicate an essential role for both the proapoptotic factor transforming growth factor $\beta 3$ [50] and the survival factor tissue inhibitor of metalloproteinase-3 [51].

Even though IGFBP-5 probably has a role in the initiation of apoptosis at involution in rodents, other IGFBPs may play a similar role in humans. IGFBP-2 is the major IGFBP in human milk, while IGFBP-1 and IGFBP-3 are present at lower concentrations and IGFBP-5 has not been detected [52,53]. Additionally, IGFBP-3 but not IGFBP-5 induces a number of cellular effects in human breast cancer cell lines [54,55]. For example, exogenous IGFBP-3 but not IGFBP-5 inhibits IGF-IR activation and blocks phosphorylation of IRS-1 in MCF-7 cells [55]. In contrast to these studies that suggest a role for IGFBP-3 in inhibiting IGFmediated effects in the human mammary gland, evidence from transgenic mice overexpressing IGFBP-3 indicates that IGFBP-3 may have a prosurvival function [28]. The physiological significance of this is not clear given that endogenous levels of IGFBP-3 are low or undetectable in the mouse mammary gland [47]. 


\section{IGF-independent actions of IGFBPs}

There is evidence that IGFBPs can regulate apoptosis not only via sequestration of IGFs, but independently of IGFs. In some cell systems, IGFBPs can induce apoptosis; for example, IGFBP-3 induces apoptosis in MCF-7 breast cancer cells [56]. This is not seen in other culture studies, however, indicating that the effects of IGFBPs depend on the cell type, the concentration and the time course of exposure. IGFBPs may also regulate the effects of different apoptotic stimuli. For example, IGFBP-3 does not induce apoptosis alone but accentuates ceramideinduced and UV-induced apoptosis in Hs578T breast cancer cells [54]. In contrast, IGFBP-4 and IGFBP-5 inhibit ceramide-induced apoptosis in these cells. Hs578T cells lack a functional IGF-IR, indicating that the effects of IGFBPs are independent of IGF-I and could be mediated by an additional receptor (Fig. 2). Cell-surface IGFBP-3 binding proteins of $20-50 \mathrm{kDa}$ are present in Hs578T cells but this putative receptor has not been fully characterized [57]. IGFBP-3 and IGFBP-5 are also ligands for the type $V$ transforming growth factor $\beta$ receptor [58]. Interestingly, IGFBP-3 and IGFBP-5 have nuclear localization sequences and are found in the nucleus of T47D human breast cancer cells, which may indicate an intracellular role for IGFBPs [59].

\section{IGFBP regulation by the ECM and matrix metalloproteinases}

IGFBPs interact with components of the ECM (Fig. 2). In this way, free IGFs can be released from the circulating IGF-IGFBP complex since ECM-associated IGFBPs have a lower affinity for IGFs. For example, IGFBP-5 binds to type III and type IV collagen, laminin and fibronectin, resulting in an eightfold reduction in its affinity for IGF-I [60,61]. Given the importance of the ECM in regulating growth factor signalling, it is possible that ECM-IGFBP interactions influence mammary function. However, there is currently little evidence to support this hypothesis.

The association of IGFBPs with the ECM also appears to reduce the sensitivity of IGFBPs to proteolysis. Proteolysis of IGFBPs results in the release of IGFs to receptors since the majority of IGFBP fragments have reduced affinity for IGFs (Fig. 2). A number of IGFBP proteases have been identified including serine proteases such as prostate-specific antigen, matrix metalloproteases including MMP-2 and MMP-9, and the disintegrin metalloprotease ADAM 12 [62-65]. Other proteolytic enzymes that are able to hydrolyse IGFBPs include plasmin, thrombin and pregnancy-associated protein A [66-68]. Proteases have a defined role in the mammary gland since cleavage of the ECM and other proteins is required for TEB invasion and side branching. Additionally, after about 3 days of involution in the rodent gland, protease-mediated basement membrane degradation occurs due to increased remodel the mammary gland back to the primary ductal structure [69]. The presence of specific IGFBP proteases in the mammary gland has not been fully determined, and further experimentation is now required to determine how proteolysis regulates IGFBP, and therefore IGF, activity in mammary development.

\section{IGFs and IGFBPs in breast cancer}

The mitogenic and survival function of IGFs is observed not only in normal mammary cells, but also in breast cancer cells. IGF-II mRNA and protein are more frequently detected in primary tumours and human breast cancer cell lines than IGF-I [70]. In addition, clinical studies show that stromal cells surrounding the normal breast epithelium secrete IGF-I while those surrounding the malignant epithelium secrete IGF-II, suggesting that transformation of breast epithelial cells may be associated with a switch from stromal IGF-I to IGF-II expression [71,72]. Additionally, the IGF-IR is overexpressed and highly activated in breast cancer tissue compared with normal or benign tissue $[73,74]$. Aspects of IGF-IR signal transduction and its relevance in breast cancer have been reviewed extensively [75].

Endocrine sources of IGF-I may also have a role in breast cancer. In some studies, circulating IGF-I levels are higher in breast cancer patients compared with normal controls [76], and high IGF levels are associated with an increased risk of breast cancer in premenopausal women [77]. In another study, however, serum IGF-I levels were not associated with overall 2-year survival [78].

A further factor associated with increased breast cancer risk is the ratio between IGF-I and IGFBP-3 levels. Elevated IGF-I and decreased IGFBP-3 levels are observed in the serum of women presenting with stage I or stage II breast cancer [79], and they correlate with an increased risk of premenopausal ductal carcinoma in situ [80]. In contrast to the reduction of IGFBP-3 in serum, IGFBP-3 is three times more prevalent within tumours showing poor prognostic features compared with those tumours with good prognostic characteristics [81]. These conflicting data may represent the different modes of actions of endocrine versus locally produced IGFBPs.

\section{IGF axis and oestrogen in breast cancer}

The synergistic effect between IGFs and oestrogens is of particular importance to breast cancer since the ER is a strong prognostic factor for breast cancer growth. In breast cancer cells, oestrogens enhance the mitogenic effect of IGFs by inducing expression of several members of the IGF family, including IGF-I and IGF-II, IGF-IR, IRS-1 and insulin-receptor substrate-2 [14,33,82-84]. The increased expression of the IGF-IR and IRS- 1 results in an enhanced response to IGF-I, leading to increased MAPK activation and therefore to proliferation. Conversely, 
removal of oestrogen results in a dramatic decrease in IRS-1 expression and MAPK activity [83]. The interplay between IGFs and oestrogens is reciprocal since IGF-I can enhance expression of the ER in breast cancer [85]. In culture studies, ER-positive breast cancer cells such as MCF-7 and T47D proliferate in response to much lower concentrations of IGF-I and IGF-II compared with ER-negative cells (e.g. MDA-MB-231) [86]. The pattern of IGFBP expression and secretion may also be related to the ER status of breast cancer cells [87]. For example, IGFBP-4 and IGFBP-5 mRNA concentrations are greater in ERpositive cancer tissues compared with in ER-negative tissue [88]. Oestrogens may also increase the level of IGFBP proteases, leading to increased proteolysis of IGFBPs and therefore to increased free IGFs [89].

\section{Anti-IGF therapies and the treatment of breast cancer}

Although there are conflicting data from clinical and epidemiological studies concerning cancer risk and prognosis, the proven role of IGFs and the IGF-IR in promoting proliferation and survival strongly implicates a role for the IGF axis in cancer. Since IGFs can protect breast cancer cells from cell death induced by radiation and chemotherapeutic agents, the survival function of IGFs could provide a mechanism of resistance to cancer therapies. To combat this, new therapeutic approaches have been developed using agents to reduce IGF-I levels. Both IGF-I and tumour incidence are reduced in transgenic mice expressing a $\mathrm{GH}$ antagonist exposed to the mammary gland carcinogen, dimethylbenz(a)anthracene [90]. Similarly, when mice bearing mammary cancer xenografts are treated with $\mathrm{GH}$ releasing hormone antagonists, IGF-I concentrations and mRNA are reduced and the tumour volume decreases [91,92].

Studies such as these indicate the value of anti-IGF therapies in the treatment of breast and other cancers where the IGF axis has been implicated. Moreover, anticancer drugs designed to inhibit other growth factor pathways can also block IGF-mediated signals. The antiestrogen ICl 182,780 reduces phosphorylation of the IGF-IR and downstream effectors in a rat mammary model [93]. Additionally, transactivation of the EGF receptor by IGF-I is blocked by an inhibitor of EGF receptor tyrosine kinase, ZD1839, thereby inhibiting the MAPK arm of the IGF signalling pathway in mammary epithelial cells [23]. ZD1839 is currently undergoing phase III clinical trials for nonsmall cell lung cancer, but may also be valuable in the treatment of breast cancer.

\section{Conclusion}

In the normal mammary gland, the IGF axis is required for development and is associated with pubertal growth, alveolar growth and involution. IGFs mediate proliferation and survival, and although it is unclear which is the predomi- nant effect in vivo, it is probable that both are important even though their contribution may depend on the stage of development. The exact function of IGFBPs in the mammary gland is far from certain, but they appear to have a role in blocking IGF-mediated survival and inducing apoptosis at involution.

While the present review has discussed how IGF signal transduction is important for mammary gland development, it is obviously just one component of a multifactorial and complex system. In the same way, the IGF axis is implicated as an important component in breast cancer. Better understanding of its function and synergistic effects with other factors may lead to the identification of new and improved therapies.

\section{Acknowledgements}

The authors thank Melissa Westwood and Keith Brennan for their valuable comments on the manuscript.

\section{References}

1. Vella V, Pandini G, Sciacca L, Mineo R, Vigneri R, Pezzino V, Belfiore A: A novel autocrine loop involving IGF-II and the insulin receptor isoform-A stimulates growth of thyroid cancer. J Clin Endocrinol Metab 2002, 87:245-254.

2. Dimitriadis $G$, Parry-Billings $M$, Bevan $S$, Dunger DB, Piva $T$, Krause U, Wegener G, Newsholme E: Effects of insulin-like growth factor-I on the rates of glucose transport and utilisation in rat skeletal muscle in vitro. Biochem $J 1992,285: 269-274$.

3. Le Roith D, Bondy C, Yakar S, Liu JL, Butler A: The somatomedin hypothesis: 2001. Endocr Rev 2001, 22:53-74.

4. Jones Jl, Clemmons DR: Insulin-like growth factors and their binding proteins: biological actions. Endocr Rev 1995, 16:3-34.

5. Clemmons DR, Cascieri MA, Camacho-Hubner C, McCusker RH, Bayne ML: Discrete alterations of the insulin-like growth factor I molecule which alter its affinity for insulin-like growth factorbinding proteins result in changes in bioactivity. $J \mathrm{Bio} / \mathrm{Chem}$ 1990, 265:12210-12216.

6. Gallego MI, Binart N, Robinson GW, Okagaki R, Coschigano KT, Perry J, Kopchick JJ, Oka T, Kelly PA, Henninghausen L: Prolactin, growth hormone, and epidermal growth factor activate Stat5 in different compartments of mammary tissue and exert different and overlapping developmental effects. Dev Biol 2001, 229:163-175.

7. Ruan W, Newman CB, Kleinberg DL: Intact and amino-terminally shortened forms of insulin-like growth factor-I induce mammary gland differentiation and development. Proc Natl Acad Sci USA 1992, 89:10872-10876.

8. Walden PD, Ruan W, Feldman M, Kleinberg DL: Evidence that the mammary fat pad mediates the action of growth hormone in mammary gland development. Endocrinology 1998, 139: 659-662.

9. Ruan W, Kleinberg DL: Insulin-like growth factor I is essential for terminal end bud formation and ductal morphogenesis during mammary development. Endocrinology 1999, 140:5075-5081.

10. Forsyth IA, Gabai G, Morgan G: Spatial and temporal expression of insulin-like growth factor-I, insulin-like growth factor-II and the insulin-like growth factor-I receptor in the sheep fetal mammary gland. J Dairy Res 1999, 66:35-44.

11. Hovey RC, MacKenzie DD, McFadden TB: The proliferation of mouse mammary epithelial cells in response to specific mitogens is modulated by the mammary fat pad in vitro. In Vitro Cell Dev Biol Anim 1998, 34:385-392.

12. Smith PJ, Wise LS, Berkowitz R, Wan C, Rubin CS: Insulin-like growth factor-I is an essential regulator of the differentiation of 3T3-L1 adipocytes. J Biol Chem 1988, 263:9402-9408.

13. Richert MM, Wood TL: The insulin-like growth factors (IGF) and IGF type I receptor during postnatal growth of the murine mammary gland: sites of messenger ribonucleic acid expression and potential functions. Endocrinology 1999, 140:454-461. 
14. Clarke RB, Howell A, Anderson E: Type I insulin-like growth factor receptor gene expression in normal human breast tissue treated with oestrogen and progesterone. $\mathrm{Br} J \mathrm{Cancer}$ 1997, 75:251-257

15. Clarke RB, Howell A, Potten CS, Anderson E: Dissociation between steroid receptor expression and cell proliferation in the human breast. Cancer Res 1997, 57:4987-4991.

16. Cao Y, Bonizzi G, Seagroves TN, Greten FR, Johnson R, Schmidt EV, Karin M: IKKalpha provides an essential link between RANK signaling and cyclin D1 expression during mammary gland development. Cell 2001, 107:763-775.

17. LeRoith D: Insulin-like growth factor I receptor signaling overlapping or redundant pathways? Endocrinology 2000, 141:1287-1288.

18. Le Roith D: Regulation of proliferation and apoptosis by the insulin-like growth factor I receptor. Growth Horm IGF Res 2000, 10A:S12-S13.

19. Zimmermann S, Moelling K: Phosphorylation and regulation of Raf by Akt (protein kinase B). Science 1999, 286:1741-1744.

20. Deeks S, Richards J, Nandi S: Maintenance of normal rat mammary epithelial cells by insulin and insulin-like growth factor 1. Exp Cell Res 1988, 174:448-460.

21. Shamay A, Cohen N, Niwa M, Gertler A: Effect of insulin-like growth factor I on deoxyribonucleic acid synthesis and galactopoiesis in bovine undifferentiated and lactating mammary tissue in vitro. Endocrinology 1988, 123:804-809.

22. Bonette SG, Hadsell DL: Targeted disruption of the IGF-I receptor gene decreases cellular proliferation in mammary terminal end buds. Endocrinology 2001, 142:4937-4945.

23. Gilmore AP, Valentijn A, Wang $P$, Ranger AM, Bundred N, O'Hare MJ, Wakeling A, Korsmeyer SJ, Streuli CH: Activation of BAD by therapeutic inhibition of epidermal growth factor receptor and transactivation by insulin like growth factor receptor. $J \mathrm{Bio}$ Chem 2002, 277:27643-27650.

24. Farrelly N, Lee Y-J, Oliver J, Dive C, Streuli CH: Extracellular matrix regulates apoptosis in mammary epithelium through a control on insulin signaling. J Cell Biol 1999, 144:1337-1348.

25. Strange R, Li F, Saurer S, Burkhardt A, Friis RR: Apoptotic cell death and tissue remodelling during mouse mammary gland involution. Development 1992, 115:49-58.

26. Metcalfe AD, Gilmore AP, Klinowska T, Oliver J, Valentijn AJ, Brown R, Ross A, MacGregor G, Hickman JA, Streuli CH: Developmental regulation of $\mathrm{Bcl}-2$ family protein expression in the involuting mammary gland. J Cell Sci 1999, 112:1771-1783.

27. Prince JM, Klinowska T, Marshman E, Lowe ET, Mayer U, Miner J, Aberdam D, Vestweber D, Gusterson B, Streuli CH: Cell-matrix interactions during development and apoptosis of the mouse mammary gland in vivo. Dev Dyn 2002, 223:497-516.

28. Neuenschwander S, Schwartz A, Wood TL, Roberts CT Jr, Henninghausen L, LeRoith D: Involution of the lactating mammary gland is inhibited by the IGF system in a transgenic mouse model. J Clin Invest 1996, 97:2225-2232.

29. Hadsell DL, Greenberg JM, Fligger CR, Baumrucker CR, Rosen $\mathrm{CJ}$ : Targeted expression of des(1-3) human insulin growth factor 1 in transgenic mice influences mammary gland development and IGF binding protein expression. Endocrinology 1996, 137:321-330.

30. Moorehead RA, Fata JE, Johnson MB, Khokha R: Inhibition of mammary epithelial apoptosis and sustained phosphorylation of Akt/PKB in MMTV-IGF-II transgenic mice. Cell Death Differ 2001, 8:16-29.

31. Schwertfeger KL, Richert MM, Anderson SM: Mammary gland involution is delayed by activated Akt in transgenic mice. Mol Endocrinol 2001, 15:867-881.

32. Hutchinson J, Jin J, Cardiff RD, Woodgett JR, Muller WJ: Activation of Akt (protein kinase B) in mammary epithelium provides a critical cell survival signal required for tumor progression. Mol Cell Biol 2001, 21:2203-2212.

33. Ruan W, Catanese V, Wieczorak R, Feldman M, Kleinberg DL: Estradiol enhances the stimulatory effect of insulin-like growth factor-I (IGF-I) on mammary development and growth hormone-induced IGF-I messenger ribonucleic acid. Endocrinology 1995, 136:1296-1302.

34. Richards RG, DiAugustine RP, Petrusz P, Clark GC, Sebastian J: Estradiol stimulates tyrosine phosphorylation of the insulinlike growth factor-1 receptor and insulin receptor substrate-1 in the uterus. Proc Natl Acad Sci USA 1996, 93:12002-12007.
35. Klotz DM, Hewitt SC, Ciana P, Raviscioni M, Lindzey JK, Foley J, Maggi A, DiAugustine RP, Korach KS: Requirement of estrogen receptor-alpha in insulin-like growth factor-1 (IGF-1)-induced uterine responses and in vivo evidence for IGF-1/estrogen receptor cross-talk. J Biol Chem 2002, 277:8531-8537.

36. Stull MA, Richert MM, Loladze AV, Wood TL: Requirement for IGF$\mathrm{I}$ in epidermal growth factor-mediated cell cycle progression of mammary epithelial cells. Endocrinology 2002, 143:1872-1879.

37. Prenzel N, Zwick E, Daub H, Leserer M, Abraham R, Wallasch C, Ullrich A: EGF receptor transactivation by $\mathrm{G}$-protein-coupled receptors requires metalloproteinase cleavage of proHB-EGF. Nature 1999, 402:884-888.

38. Moro L, Venturino M, Bozzo C, Silengo L, Altruda F, Beguinot L, Tarone $G$, Defilippi $P$ : Integrins induce activation of EGF receptor: role in MAP kinase induction and adhesion-dependent cell survival. EMBO J 1998, 17:6622-6632.

39. Roskelley CD, Srebrow A, Bissell MJ: A hierarchy of ECM-mediated signalling regulates tissue-specific gene expression. Curr Opin Cell Biol 1995, 7:736-747.

40. Streuli $\mathrm{CH}$, Edwards GM: Control of normal mammary epithelial phenotype by integrins. J Mamm Gland Biol Neoplasia 1998, 3:151-163.

41. Miranti CK, Brugge JS: Sensing the environment: a historical perspective on integrin signal transduction. Nat Cell Biol 2002, 4:E83-E90.

42. Vuori K, Ruoslahti E: Association of insulin receptor substrate1 with integrins. Science 1994, 266:1576-1578.

43. Lee Y-J, Streuli CH: Extracellular matrix selectively modulates the response of mammary epithelial cells to different soluble signaling ligands. J Biol Chem 1999, 274:22401-22408.

44. Woodward TL, Xie J, Fendrick JL, Haslam SZ: Proliferation of mouse mammary epithelial cells in vitro: interactions among epidermal growth factor, insulin-like growth factor I, ovarian hormones, and extracellular matrix proteins. Endocrinology 2000, 141:3578-3586.

45. Shaw LM: Identification of insulin receptor substrate 1 (IRS-1) and IRS-2 as signaling intermediates in the alpha6beta4 integrin-dependent activation of phosphoinositide $3-\mathrm{OH}$ kinase and promotion of invasion. $\mathrm{Mol} \mathrm{Ce} / \mathrm{Bio}$ 2001, 21:5082-5093.

46. Wood TL, Richert MM, Stull MA, Allar MA: The insulin-like growth factors (IGFs) and IGF binding proteins in postnatal development of murine mammary glands. J Mammary Gland Biol Neoplasia 2000, 5:31-42.

47. Tonner E, Barber MC, Travers MT, Logan A, Flint DJ: Hormonal control of insulin-like growth factor binding protein-5 production in the involuting mammary gland of the rat. Endocrinology 1997, 138:5101-5107.

48. Chapman RS, Duff EK, Lourenco PC, Tonner E, Flint DJ, Clarke $A R$, Watson CJ: A novel role for IRF-1 as a suppressor of apoptosis. Oncogene 2000, 19:6386-6391.

49. Chapman RS, Lourenco PC, Tonner E, Flint DJ, Selbert S, Takeda K, Akira S, Clarke AR, Watson CJ: Suppression of epithelial apoptosis and delayed mammary gland involution. Genes Dev 1999, 13:2604-2616.

50. Nguyen AV, Pollard JW: Transforming growth factor beta3 induces cell death during the first stage of mammary gland involution. Development 2000, 127:3107-3118.

51. Fata JE, Leco KJ, Voura EB, Yu HY, Waterhouse P, Murphy G, Moorehead RA, Khokha R: Accelerated apoptosis in the Timp3-deficient mammary gland. J Clin Invest 2001, 108:831-841.

52. Eriksson U, Duc G, Froesch ER, Zapf J: Insulin-like growth factors (IGF) I and II and IGF binding proteins (IGFBPs) in human colostrum/transitory milk during the first week postpartum: comparison with neonatal and maternal serum. Biochem Biophys Res Commun 1993, 196:267-273.

53. Breier BH, Milsom SR, Blum WF, Schwander J, Gallaher BL, Gluckman PD: Insulin-like growth factors and their binding proteins in plasma and milk after hormone-stimulated galactopoiesis in normally lactating women. Acta Endocrinol Copenh 1993, 129:427-435.

54. Perks CM, Bowen S, Gill ZP, Newcomb PV, Holly JM: Differential IGF-independent effects of insulin-like growth factor binding proteins (1-6) on apoptosis of breast epithelial cells. J Cell Biochem 1999, 75:652-664.

55. Ricort J-M, Binoux M: Insulin-like growth factor (IGF) binding protein-3 inhibits type I IGF receptor activation independently of its IGF binding affinity. Endocrinology 2001, 142:108-113. 
56. Nickerson $T$, Huynh $H$, Pollak M: Insulin-like growth factor binding protein-3 induces apoptosis in MCF7 breast cancer cells. Biochem Biophys Res Commun 1997, 237:690-693.

57. Oh $Y$, Muller $H$, Pham H, Rosenfeld RG: Demonstration of receptors for insulin-like growth factor binding protein-3 on Hs578T human breast cancer cells. J Biol Chem 1993, 268: 26045-26058.

58. Leal SM, Huang SS, Huang JS: Interactions of high affinity insulin-like growth factor binding proteins with the type $\mathbf{V}$ transforming-receptor in mink lung epithelial cells. $J$ Biol Chem 1999, 274:6711-6717.

59. Schedlich LJ, Young TF, Firth SM, Baxter RC: Insulin-like growth factor-binding protein (IGFBP)-3 and IGFBP-5 share a common nuclear transport pathway in T47D human breast carcinoma cells. J Biol Chem 2000, 29:18347-18352.

60. Jones Jl, Gockerman A, Busby WH Jr, Camacho-Hubner C, Clemmons DR: Extracellular matrix contains insulin-like growth factor binding protein-5: potentiation of the effects of IGF-I. $J$ Cell Biol 1993, 121:679-687.

61. Parker A, Clarke JB, Busby WH Jr, Clemmons DR: Identification of the extracellular matrix binding sites for insulin-like growth factor binding protein-5. J Biol Chem 1996, 271:13523-13529.

62. Cohen P, Graves HC, Peehl DM, Kamarei M, Giudice LC, Rosenfeld RG: Prostate-specific antigen (PSA) is an insulin-like growth factor binding protein-3 protease found in seminal plasma. J Clin Endocrinol Metab 1992, 75:1046-1053.

63. Collett-Solberg PF, Cohen P: The role of the insulin-like growth factor binding proteins and the IGFBP proteases in modulating IGF action. Endocrinol Metab Clin North Am 1996, 25:591614.

64. Nam TJ, Busby WH Jr, Clemmons DR: Human fibroblasts secrete a serine protease that cleaves insulin-like growth factor-binding protein-5. Endocrinology 1994, 135:1385-1391.

65. Loechel F, Fox JW, Murphy G, Albrechtsen R, Wewer UM: ADAM 12-S cleaves IGFBP-3 and IGFBP-5 and is inhibited by TIMP3. Biochem Biophys Res Commun 2000, 278:511-515.

66. Lalou C, Silve C, Rosato R, Segovia B, Binoux M: Interactions between insulin-like growth factor-I (IGF-I) and the system of plasminogen activators and their inhibitors in the control of IGF-binding protein-3 production and proteolysis in human osteosarcoma cells. Endocrinology 1994, 135:2318-2326.

67. Zheng B, Clarke JB, Busby WH J, Duan C, Clemmons DR: Insulin-like growth factor-binding protein-5 is cleaved by physiological concentrations of thrombin. Endocrinology 1998, 139:1708-1714.

68. Overgaard MT, Boldt HB, Laursen LS, Sottrup-Jensen L, Conover CA, Oxvig C: Pregnancy-associated plasma protein-A2 (PAPPA2), a novel insulin-like growth factor-binding protein-5 proteinase. J Biol Chem 2001, 276:21849-21853.

69. Talhouk RS, Bissell MJ, Werb Z: Coordinated expression of extracellular matrix-degrading proteinases and their inhibitors regulates mammary epithelial function during involution. J Cell Biol 1992, 118:1271-1282.

70. Werner H, LeRoith $D$ : The insulin-like growth factor-I receptor signaling pathways are important for tumorigenesis and inhibition of apoptosis. Crit Rev Oncogene 1997, 8:71-92.

71. Paik S: Expression of IGF-I and IGF-II mRNA in breast tissue. Breast Cancer Res Treat 1992, 22:31-38.

72. Yee D, Paik S, Lebovic GS, Marcus RR, Favoni RE, Cullen KJ, Lippman ME, Rosen N: Analysis of insulin-like growth factor $\mathrm{I}$ gene expression in malignancy: evidence for a paracrine role in human breast cancer. Mol Endocrinol 1989, 3:509-517.

73. Papa V, Gliozzo B, Clark GM, McGuire WL, Moore D, FujitaYamaguchi Y, Vigneri R, Goldfine ID, Pezzino V: Insulin-like growth factor-I receptors are overexpressed and predict a low risk in human breast cancer. Cancer Res 1993, 53:3736-3740.

74. Resnik JL, Reichart DB, Huey K, Webster NJ, Seely B: Elevated insulin-like growth factor I receptor autophosphorylation and kinase activity in human breast cancer. Cancer Res 1998, 58: 1159-1164.

75. Zhang $X$, Yee D: Tyrosine kinase signalling in breast cancer: insulin-like growth factors and their receptors in breast cancer. Breast Cancer Res 2000, 2:170-175.

76. Pollak M: Endocrine effects of IGF-I on normal and transformed breast epithelial cells: potential relevance to strategies for breast cancer treatment and prevention. Breast Cancer Res Treat 1998, 47:209-217.
77. Hankinson SE, Willett WC, Colditz GA, Hunter DJ, Michaud DS, Deroo B, Rosner B, Speizer FE, Pollack M: Circulating concentrations of insulin-like growth factor-I and risk of breast cancer. Lancet 1998, 351:1393-1396.

78. Bhatavdekar JM, Patel DD, Karelia NH, Vora HH, Ghosh N, Shah NG, Balar DB, Trivedi SN: Tumor markers in patients with advanced breast cancer as prognosticators: a preliminary study. Breast Cancer Res Treat 1994, 30:293-297.

79. Bruning PF, Van Doorn J, Bonfrer JM, Van Noord PA, Korse CM, Linders TC, Hart AA: Insulin-like growth-factor-binding protein 3 is decreased in early-stage operable pre-menopausal breast cancer. Int J Cancer 1995, 62:266-270.

80. Bohlke K, Cramer DW, Trichopoulos D, Mantzoros CS: Insulinlike growth factor-I in relation to premenopausal ductal carcinoma in situ of the breast. Epidemiology 1998, 9:570-573.

81. Rocha RL, Hilsenbeck SG, Jackson JG, Lee AV, Figueroa JA, Yee $D$ : Correlation of insulin-like growth factor-binding protein-3 messenger RNA with protein expression in primary breast cancer tissues: detection of higher levels in tumors with poor prognostic features. J Natl Cancer Inst 1996, 88:601-606.

82. Stewart AJ, Johnson MD, May FE, Westley BR: Role of insulinlike growth factors and the type I insulin-like growth factor receptor in the estrogen-stimulated proliferation of human breast cancer cells. J Biol Chem 1990, 265:21172-21178.

83. Lee AV, Jackson JG, Gooch JL, Hilsenbeck SG CoronadoHeinsohn E, Osbourne CK, Yee D: Enhancement of insulin-like growth factor signaling in human breast cancer: estrogen regulation of insulin receptor substrate-1 expression in vitro and in vivo. Mol Endocrinol 1999, 13:787-796.

84. Lee AV, Darbre P, King RJ: Processing of insulin-like growth factor-II (IGF-II) by human breast cancer cells. Mol Cell Endocrinol 1994, 99:211-220.

85. Clemmons DR, Camacho HC, Coronado E, Osbourne CK: Insulin-like growth factor binding protein secretion by breast carcinoma cell lines: correlation with estrogen receptor status. Endocrinology 1990, 127:2679-2686.

86. Karey KP, Sirbasku DA: Differential responsiveness of human breast cancer cell lines MCF-7 and T47D to growth factors and 17 beta-estradiol. Cancer Res 1988, 48:4083-4092.

87. Figueroa JA, Sharma J, Jackson JG, McDermott MJ, Hilsenbeck SG, Yee D: Recombinant insulin-like growth factor binding protein-1 inhibits IGF-I, serum and estrogen-dependent growth of MCF-7 human breast cancer cells. J Cell Physiol 1993 157:229-236.

88. McGuire SE, Hilsenbeck SG, Figueroa JA, Jackson JG, Yee D: Detection of insulin-like growth factor binding proteins (IGFBPs) by ligand blotting in breast cancer tissues. Cancer Lett 1994, 77:25-32.

89. Mathieu M, Vignon F, Capony F, Rochefort H: Estradiol downregulates the mannose-6-phosphate/insulin-like growth factor-II receptor gene and induces cathepsin-D in breast cancer cells: a receptor saturation mechanism to increase the secretion of lysosomal proenzymes. Mol Endocrinol 1991, 5: 815-822.

90. Pollak M, Blouin MJ, Zhang JC, Kopchick JJ: Reduced mammary gland carcinogenesis in transgenic mice expressing a growth hormone antagonist. Br J Cancer 2001, 85:428-430.

91. Szepeshazi K, Schally AV, Armatis P, Groot K, Hebert F, Feil A, Varga JL, Halmos G: Antagonists of GHRH decrease production of GH and IGF-I in MXT mouse mammary cancers and inhibit tumor growth. Endocrinology 2001, 142:4371-4378.

92. Friend F: Cancer and the potential place for growth hormone receptor antagonist therapy. Growth Horm IGF Res 2001, 11: S121-S123.

93. Chan TW, Pollak M, Huynh $\mathrm{H}$ : Inhibition of insulin-like growth factor signaling pathways in mammary gland by pure antiestrogen ICI 182,780. Clin Cancer Res 2001, 7:2545-2554. 